\title{
SEXUAL HEALTH and the professional nurse
}

\section{CAROLE WELMAN}

\section{Senior Nursing Service Manager, Family Planning Division, Department of Health and Welfare}

OPSOMMING
Menslike seksualiteit, as 'n psigofisio-
logiese stelsel, is met reg 'n deel van
die arbeidsveld van gesondheidsprak-
tisyns. Dit is egter 'n veld wat agter-
weë bly weens die sensitiewe aard
daarvan. Die verpleegkundige kan 'n
belangrike bydrae tot die bevorde-
ring van seksuele gesondheid lewer en
het daarin 'n opvoedkundige, tera-
peutiese en breë gemeenskapsrol.
Die Gesinsbeplanningsafdeling van
die Departement van Gesondheid en
Welsyn het poste geskep vir hoofver-
pleegkundiges om alle gesinsbeplan-
ningsverpleegkundiges in die veld op
te lei. Die opleiding sal gegee word
aan die hand van die PLISSIT-model
wat vlakke van hulpverlening vir sek-
suele probleme bepaal. Gesinsbe-
planningsverpleegkundiges sal vir
dienslewering op vlak 1 opgelei word.

\section{HUMAN SEXUALITY}

Sexuality is recognised as a psychophysiologic system that is distinct from and yet interrelated with the reproductive and urinary systems. A female has the capacity for reproduction for less than half the normal life span, but sexuality operates throughout her life. In the male, both ejaculatory fluid and urine pass through the urethra, one organ serving different functions.

Sex is a psychophysiological system which, legitimately, should be assessed by the nurse in every field. In hospital, the patient's sexual history is part of a total history; in a primary health care setting, sex should be explored during the review of the systems; and in family planning the nurse is a kingpin in screening for sexual health. However, education in normal human sexuality is not provided in the training of nurses (or medical students for that matter) and consequently nurses lack essential know- ledge and competence in this field. Patients with sexual problems who turn to them for advice often encounter a negative reception or a superficial reply.

Unfortunately, remnants of the Victorian era are still evident in our society and sex is still not a subject for open discussion despite an increasing number of people (of all ethnic groups) who are seeking professional help for what they regard as problems or dissatisfaction in their sex lives.

A major obstacle which has to be removed before a nurse can become an effective practitioner in the sexual health field is, therefore, one of personal embarrassment and discomfort. The myths, fallacies and guilts inculcated in us from the time we were old enough to understand must now be broken down and the arduous task of re-teaching must begin. Nurses will have to be taught to accept their own sexuality, to be aware of biases and to accept with understanding and tolerance the moral, aesthetic and religious sensibilities of the people with whom they have to deal.

\section{SEX COUNSELLING}

Human sexuality is a proper concern of health practitioners and the treatment of sex problems is an integral part of preventive and therapeutic health care. All nurses (and especially family planning nurses) encounter people seeking advice, guidance, information or therapy for sexual problems. They should be in a position to diagnose and treat, at their level of competence, not only the physical condition but also educational deficiencies in their patients or clients.

It is significant that the people seeking help for sexual problems constitute probably less than $10 \%$ of the total number of people with problems. Because of the socio-cultural sex-shroud, the greater percentage will not spontaneously express their needs or request help until their counsellor has paved the way for them. Also of significance is that in $90 \%$ of sex problems couples, or individuals, only need someone to listen who can identify their problems and lead them through a therapeutic process. It is estimated that less than $10 \%$ of all sex problems need psychotherapy.

Reliable data are now available documenting the therapeutic effects of sexuality education programmes. There is no doubt that misunderstanding plays a significant role in the development of sex problems. In practice there have been many instances when the simple sharing of sex information and concepts, without formal sex therapy, has enabled people to resolve their sexual difficulties.

In summary we can say that sex counselling therapy is a neglected field because of:

- professionals who are not even aware that they are guilty of perpetuating myths, guilts and fallacies themselves

- communication deficiencies

- conflicting socio-cultural value systems

- the amount of time necessary in all aspects (education/counselling/therapy) of this field.

An area in sexuality fraught with problems and anxieties which needs to be especially highlighted is that of adolescent sexuality. Contrary to widespread belief all teenage cultures, whatever their socio-cultural heritage, have one common denominator, vis. that emotions play a much greater role than intellectual abstractions, and that for each individual the $I$ and here and now are 
FAMILY PLANNING PROGRAMME

\begin{tabular}{|c|c|c|c|}
\hline $\begin{array}{l}\text { PROFESSIONAL } \\
\text { COMPETENCE } \\
\text { REQUIRED }\end{array}$ & $\begin{array}{l}\text { LEVEL OF } \\
\text { ASSESSMENT }\end{array}$ & $\begin{array}{l}\text { PERSONAL } \\
\text { COMPETENCE } \\
\text { REQUIRED }\end{array}$ & $\begin{array}{l}\text { LEVELS OF } \\
\text { THERAPEUTIC } \\
\text { INTERVENTION }\end{array}$ \\
\hline $\begin{array}{l}\text { LEVEL 1 } \\
\text { Professional nurse }\end{array}$ & $\begin{array}{l}\text { Reproductive/ health } \\
\text { history }\end{array}$ & $\begin{array}{l}\text { - comfortable discus- } \\
\text { sing sexuality } \\
\text { - good listener } \\
\text { - non-judgemental } \\
\text { - familiar with typical } \\
\text { societal attitudes } \\
\text { - no special knowledge }\end{array}$ & $\begin{array}{l}\text { limited sex education } \\
\text { - limited information } \\
\text { about sexual feelings, } \\
\text { behaviour and myths } \\
\text { - reassurance } \\
\text { - refer to levels } 2 \text { or } 3 \text { if } \\
\text { necessary }\end{array}$ \\
\hline $\begin{array}{l}\text { LEVEL } 2 \\
\text { Professional nurse with } \\
\text { training in sex education } \\
\text { and counselling }\end{array}$ & Sexual history & $\begin{array}{l}\text { - qualities necessary for } \\
\text { level } 1 \\
\text { - additional knowledge } \\
\text { of human sexuality } \\
\text { and disability }\end{array}$ & $\begin{array}{l}\text { sex education and coun- } \\
\text { selling } \\
\text { specific information } \\
\text { about sex and sexual- } \\
\text { ity } \\
\text { concise suggestions } \\
\text { and guidance regard- } \\
\text { ing sexual values, be- } \\
\text { liefs and behaviour } \\
\text { refer to level } 3 \text { if ne- } \\
\text { cessary }\end{array}$ \\
\hline $\begin{array}{l}\text { LEVEL } 3 \\
\text { Professional nurse, } \\
\text { physician, psychologist, } \\
\text { social worker - all qua- } \\
\text { lified as trained sex thera- } \\
\text { pists }\end{array}$ & Sexual-problem history & $\begin{array}{l}\text { - qualities necessary for } \\
\text { levels } 1 \text { and } 2 \\
\text { - ability to give accu- } \\
\text { rate neurological, } \\
\text { physical and psycho- } \\
\text { logical information }\end{array}$ & $\begin{array}{l}\text { Sex therapy } \\
\text { - individual or group } \\
\text { therapy } \\
\text { couple therapy } \\
\text { refer to level } 4 \text { if ne- } \\
\text { cessary }\end{array}$ \\
\hline $\begin{array}{l}\text { LEVEL } 4 \\
\text { Professional nurse, } \\
\text { physician, psychologist, } \\
\text { social worker - all with } \\
\text { subordinate specialities } \\
\text { in psychiatry and sex } \\
\text { therapy }\end{array}$ & $\begin{array}{l}\text { Psychiatric and psycho- } \\
\text { sexual history }\end{array}$ & $\begin{array}{l}\text { - knowledge and skill to } \\
\text { apply a specific pro- } \\
\text { gramme of services to } \\
\text { a particular problem } \\
\text { or concern }\end{array}$ & $\begin{array}{l}\text { Eclectic approach } \\
\text { - intensive individual } \\
\text { psychotherapy, sex } \\
\text { therapy and marital } \\
\text { therapy }\end{array}$ \\
\hline
\end{tabular}

'Adapted from Rosalyn Jones Watts' modified Annon's PLISSIT Model.

pressing elements in the decisionmaking process.

Most adults have not recognised the nature of young people's emotional and sexual relationships. They tend to judge them in outmoded terms and do not offer the kind of help and support young people need. What adolescents need is much better information about their bodies, the bodies of the other sex, the psychology of human relationships, a chance to explore and question their own attitudes and beliefs, and above all some help in learning how to communicate intimately, that is, how to talk about feelings, sex, contraception, fidelity and trust to name just a few important topics. ${ }^{2}$

\section{TRAINING NURSES FOR PROMOTING SEXUAL} HEALTH

Briefly, any nurse's contribution in the field of healthy sexuality can be through:

- listening and clarifying problems,

- educating,

- diagnosing and referring pathology for treatment,

- using the physical examination to show a woman her genitals and teach her about her body,

- discussing the impact of contraception on sex,

- encouraging appropriate reading,

- encouraging self-help,

- encouraging improved com- munication between clier: and sexual partner directly, by seeing them together, or indirectly by

- helping to change attitudes and feelings,

- referring for further help,

- preventing potential sexual difficulties.

With all of this in mind, the Family Planning Division of the Department of Health and Welfare has created ten posts of Chief Professional Nurse for its ten departmental regions in the country. Nurses appointed to these posts will receive comprehensive training in all aspects of human sexuality to equip them for training family planning nurses to assist people to conduct their sexual lives successfully. 
To become competent in this task the nurse needs basic knowledge of human sexuality and she must be taught to feel comfortable in discussing sexuality with both able and disabled people as well as being aware of resources available on sexuality and disability. The nurse will need training to enable her to deal with sexual issues on predetermined levels of competency, and to be able to refer the client to an appropriate source where necessary.

In addition, she needs to be empathetic and sensitive to individual differences, and must be trained in the ability not to project her own sexual morals or values onto the client.

The training of nurses will be in accordance with the PLISSIT model developed by Dr Jack S. Annon to conceptualise levels of intervention in sexual matters related to all persons. This model outlines four levels of involvement which the service-provider can pursue. Each additional level requires a greater amount of comfort, knowledge and skill on the part of the provider. It can be used by a variety of helping professionals and allows for a broad range of service delivery, dependent on the level of competence of the provider.

Initially, all family planning nurses rendering a service will be trained at level 1 and chief professional nurses at level 2 . The four levels of approach to questions related to sexuality are:

Level 1: Permission

Level 2: Limited Information $\underline{\mathrm{LI}}$

Level 3: Specific Suggestions SS

Level 4: Intensive Therapy IT

Table 1 provides further detail regarding the professional competence required, level of assessment, personal competence required and levels of therapeutic intervention at each level, as adapted for the training of family planning nurses

\section{ROLE OF THE NURSE}

The role of the health practitioner in sex education for the preservation of both physical and mental health, the social implications of sexual conduct, and the understanding of sexuality for responsible parenthood can be divided into three major categories - educa- tional, therapeutic and community. ${ }^{4}$ The family planning nurse has an important role in each of these three categories.

\section{Educational Role}

\section{- Preventive}

- sex edcucation in terms of individual education

- aiding parents to understand their roles

- helping teachers in their work with children

- helping children and adolescents to understand their development

\section{- Marriage preparation}

- advising on matters such as sex adjustment and contraception

\section{- Community enlightenment}

- stressing the preventive value of sex education.

In addition to the knowledge and skills pertaining to education in human sexuality, this role demands from the nurse a good understanding of the cultures and sub-cultures in which she practises. Considerable competence in educational planning and practice is also required.

\section{Therapeutic Role}

\section{- Individuals and families with problems \\ - unwanted pregnancy \\ - premarital and extra-marital sex relationships \\ — infertility \\ - sexually transmitted diseases.}

\section{Community Role}

- Services to people with sex-related problems

If human sexuality is recognised as a health component, services to people with sex-related problems should become an integral part of the total programme of community heaith care.

- Responsible attitudes in use of media

There is evidence that popular literature, widely read by ill-informed people, can produce anxiety and distress and can lead to demands for unrealistic levels of sexual performance. This calls for an attempt to bring about responsible attitudes in the use of mass media for public sex education.

\section{- Sexual misdemeanours}

The public should be educated that some forms of sexual behaviour are rooted in emotional disturbance and yield more readily to psychotherapy than to punitive measures.

\section{CONCLUSION}

Sexuality is part of all the activities in which a person takes part daily it is an expression of personality. In other words it is an integration of the physical, emotional, social, and intellectual aspects of an individual's personality which expresses maleness or femaleness.

The vast number of problems that involve aspects of sexual functioning, the increase in the demand for services, and the expectation of patients and clients for competent health practitioners in the management of problems have contributed toward a situation of Hobson's choice. The nurse, or any health practitioner for that matter, must learn the basic skills of sex counselling or neglect a highly significant and important aspect of practice.

\section{REFERENCES}

1. Sarrell, P.M. (1982). Workshop - Sexuatiry in Healt and Disease. Attended April 1982, UCT, Cape Town

2. Sarrel, L.J.; Sarrel, P.M. (1979). Sexual unfoldingsexual Development and Sex Therapies in Late Adole sence, Little, Brown and Company.

3. Watts, Rosalyn Jones. (1979). Dimensions of Sexual Health, American Journal of Nursing. September 1979 pp 1568-1572.

4. Mace; Bannerman; Burton. (1974). The Teaching of Human Sexualiry in Schools for Health Professionals. Public Health Papers 57. Geneva. WHO.

5. Green, Richard (editor). (1980). Human Sexuality - a Health Practitioner's Text. Williams and Wilkins.

6. Cornelius et al, (1982). Who Cares? A Handbook on Sex Education and Counselling Services for Disabled Peopie. University Park Press.

7. Emphasis - Family Sexuality Education: Meeting Today's Challenge. New York. Planned Parenthood Federation. Summer 1982.

8. Schiller, Patricia. (1977). Creative Approach to Sex Education and Counselling. Association Press.

9. Krohne, Eric C. (1982). Sex Therapy Handbook. MTP Press. 1982.

10. Hawton, K. (1980). Training in the Management of Psychosexual Problems. Medical Educarion. 1980. 14, pp 214-218.

11. Sadock, V.; Sadock, B.; Kaplan. (1975). Comprehen sive Sex Therapy Training: A New Approach. Am. J. Psyshiaury 132;8. August 1975

12. Gray, Charlotte. (1982). Sexual Myths Still Persist CMA Journal April 15, 1982. Vol 126 pp 981-987.

13. Bentley, Norma. (1982). Plugging the Gap. Nursing Times. January 13, 1982. pp 56-57.

14. Simpson, S.D. (1982). Treatment of Sexual Dysfunction by Behavioural Psychotherapy. Nursing Times. January 13, 1982. pp 53-55.

15. Sager, Clifford J. The Role of Sex Therapy in marita Therapy. AM. J. Psychiatry. 133:5. May 1976. pp 555. 558.

16. Sparks, B.L.W. (1981). Sexual Counselling of the Family. S.A. Medical Journal. 28 February 1981. $\mathrm{pp}$ 291-294. 